\title{
Mensagem do Presidente SBACV-MG
}

Prezados colegas Angiologistas e Cirurgiões Vasculares,

O SIF 2013 é um evento com lugar de destaque no calendário de congressos que ocorrem este ano no Brasil.

Tive o privilégio de contar com grandes colegas de nossa regional na organização do evento e agradeço a todos que compõem a diretoria da SBACV-MG biênio 2012/2013.

Ao Dr. Francisco Bastos, deixo também meus especiais agradecimentos por ter aceitado a missão de presidir o SIF 2013 de forma tão dedicada e brilhante. A idéia dos Anais do congresso, que agora virou uma realidade, tornou possível deixar registrado na história grandes discussões e avanços que sem sombra de dúvida nos orientarão em nossa prática do dia a dia, beneficiando sobremaneira nossos pacientes.

Parabéns a todos que fizeram parte desta história, 